\title{
Ladislav Vychodil's Approach to Designing Stages for Shakespeare Home and Abroad
}

Zuzana Koblišková

\begin{abstract}
This essay aims to present the most significant approaches Vychodil used for designing stages for Shakespeare plays, and to compare the designs with others, more typical of $V y$ chodil's aesthetic practice. The paper will, therefore, ask the following questions: (i) what demands do Shakespeare's plays make on the designer? and (ii) how does Vychodil, in particular, respond to these requirements? In constructing my argument, I have relied not only on well-known resources and monographs, but I have also used material from the archives of the Jerome Lawrence and Robert E. Lee Theatre Research Institute in Columbus, Ohio, which have not hitherto been sufficiently studied by other researchers.
\end{abstract}

\section{Keywords}

Ladislav Vychodil, Shakespeare scenography, Slovak National Theatre, Jarka M. Burian, Oslo, Santa Barbara CA 
$[\ldots]$ once you start working somewhere else than home, the work as if meant more [...] especially when you start working abroad [...] (ČINČERA 1995)

(Ladislav Vychodil)

\section{Introduction}

Certainly, there is no need to introduce Ladislav Vychodil within the context of Czech and Slovak scenography. He was born in 1920 in Moravia; yet he has been called 'the doyen of Slovak scenography and the founder of the scenography department at the Academy of Performing Arts in Bratislava' (Hudobný život 2005: 8). Vychodil was born Czech (coincidently, in the same year that the Slovak National Theatre was 'born') and it might have been fate that throughout his whole life, Vychodil fought fiercely to help create a Slovak theatre tradition. He became Slovak in his scenographic style, as, according to his student Vladimír Suchánek, he always tried to find a way to differentiate his work from the central tendencies that his contemporary, Josef Svoboda, had been developing in Czech scenography. ${ }^{1}$ Soon after his training as a painter and technical sketch artist in Prague and a short study at the School of Applied Arts in Brno, Vychodil was offered a position at the Slovak National Theatre. František Tröster, whom he sought as an advisor during his studies in Prague, helped him to establish his career in Bratislava. Both his talent and the circumstances in the Slovak National Theatre allowed him to take on the role of the chief stage designer at the age of twenty-five.

\section{Vychodil and Shakespeare}

Vychodil created stage designs for more than five hundred and seventy productions, nearly fifty of those outside Czech and Slovak theatres, and twenty-five of all of those were stages for Shakespeare. ${ }^{2}$ Nine of the Shakespeare productions were for Slovak theatres (mainly the Slovak National Theatre and the New Stage of the National Theatre in Bratislava), and thirteen for Czech theatres. Broken down into individual productions, Vychodil designed stages for nine Shakespeare plays only once (three of them were in Bohemia, four in Slovakia and two outside Czechoslovakia). On the other hand, he had a chance to create four various stages for Hamlet, hence only once in Slovakia (1950 at the Slovak National Theatre). Vychodil also designed scenes for three productions of The Taming of the Shrew (Bohemia, Slovakia, Bulgaria) and three of The Merry Wives of Windsor (two in Slovakia and one in Bohemia). He designed the Twelfth Night or What You Will (one in Slovakia and one in Bohemia) and Much Ado about Nothing (both in Bohemia) twice each.

1 SUCHÁNEK, V. 15. 11. 2017. Personal communication at Café Berlinka in Bratislava (11:00-13:00).

2 I refer readers to the list of Vychodil's scenography for Shakespeare at the end of this study. 
Vychodil's work developed through several stages, and they all manifested in those twenty-five scenography designs for Shakespeare productions. The crucial aspect of this study is to show how Vychodil used the opportunities to design in foreign countries using Shakespeare productions as a common denominator. He was quite hesitant to work as a stage designer outside the Slovak National Theatre until the 1960s, precisely until he met Alfréd Radok. According to his own words, this was due to his effort to build the theatre, enhance the theatre workshops and further his efforts to teach new generations of scenographers at the newly established Academy of Performing Arts in Bratislava. Over the strictest period of Socialism, the so-called period of 'building' [1948-1956], the newly established state theatres around Slovakia needed professionals, and Vychodil felt responsible for teaching them and providing for the theatres. Subsequently, however, he realised that

Once you start working somewhere else than home the work somehow seemed to mean more [...] especially when you start working abroad [he meant outside Czechoslovakia] as if finally, you do something for real. Until the work is proven abroad, you can do whatever you like at home it would still mean nothing. (ČINČERA 1965)

The realisation came after the hardest implementation of dogmatic ideas connected to the cult of the personality of Stalin was destroyed from the late 1950s onwards, and significant changes in cultural policy became evident within the following years. While for Vychodil meeting Radok meant to step outside of his box, or out of his teacher's [Tröster] shadow, for Alfréd Radok it meant a step back from his promising career developing innovative theatre techniques using the Laterna Magica with Josef Svoboda. Although Radok never directed a Shakespeare play with Vychodil as a designer, the impact of their collaboration on Vychodil's scenography for Shakespeare, and especially in Czech theatres, was essential. Vychodil became known beyond the borders of Czechoslovakia also thanks to that particular shift in his style after meeting Radok. However, he was invited to stage Shakespeare only three times outside Czech and Slovak territories. It was for The Taming of the Shrew (direction: E. Michajlova) Teatr Asparuch Paunov, Mikhaylovgrad, 1981; Comedy of Errors (direction: J. Cazalet) Concordia University, Montreal, 1984 and Romeo and Juliet (direction: P. Løkkeberg) Det Norske Teatret, Oslo, 1985.

I have organised my analyses according to the central artistic tendencies in $\mathrm{Vy}$ chodil's scenography, and I will concentrate on the similarities, and visual elements applied in various conditions and different time periods. Although Vychodil did have a style that was recognisable, it had some significant variations that evolved chronologically but had also reappeared during his career as if reaffirmations or attempts to prove that 'whatever works at home works everywhere else' (ČINČERA 1965). He described the unique style of a scenographer as more complicated than the style of a visual painter. A scenographer's choice of themes is quite restricted, and therefore his or her unique style is based on the structure of his or her philosophy and not on the visual effects (MOJŽIŠOVÁ 2009: 265). 
In the 1940s, Vychodil's style was still profoundly rooted in František Tröster's work with colour and light. Later, Vychodil put more emphasis on structure and architecture along with classical monumentality according to the demands of the guidelines for Socialist Realist art in the 1950s. Since the collaboration with Radok in the 1960s, Vychodil had treated space with a particular emphasis on the utility of stage properties and experimented with various materials returning to Tröster's training. He described his scenography before 1961 (prior to meeting Radok) as 'dead monuments in the background' (MOJŽIŠOVÁ 2009: 263). Those principles were valid for his work as a whole but may also be explained through his Shakespeare productions.

The first Shakespeare production Vychodil got involved with as a stage designer, The Taming of the Shrew in 1943, was produced by the Beskydy Theatre in Bohemia. The stage consisted of a movable decking with a chess-board pattern. The height and the aptitude of the decking represented changes in the environment. The decking moved thanks to seven oversized metal rings and full flat linen ropes. Both the idea of uneven decking and also the chess pattern or other geometric division of the space can also be traced in previous works of Tröster. ${ }^{3}$ The utility details were in correspondence with a sketch-like or linear chandelier made of straw that was to resemble the Baroque era. The delicate round soft lines were in sharp contrast to the geometry of the chess pattern as well as the cascading surface of the decking. Although the set Vychodil created might seem quite simple, it was probably very dominant due to the abstract geometrically laid out space. Unfortunately, I haven't been able to trace more archive material to support my thesis.

Vychodil used cascading wooden decking but without any patterns also in the production of The Taming of the Shrew at the New Stage Theatre of The Slovak National Theatre in Bratislava in 1946. The Baroque linear model used before as a chandelier became a vertical panel. The stage was more specific than the one in 1943, although still relying on symbols. The simplicity and a relative convention might have been caused by the fact that the New Stage of the Slovak National Theatre was a newly established theatre, and as the programme of the play stated, the production was intended for 'the engineers of future, builders of the state, workers of the two-year plan' (KARVAŠ 1946). The years of progressive ideas in scenography implemented at the Slovak National Theatre by Tröster and his favourite director Viktor Šulc in the 1930s were over. And the freedom of the theatre director Antonín Drašar (1931-1938) to take the director, scenographer and the actors of play, he intended to produce in Bratislava, to see a premiére of a production of that play in Vienna was no longer a mundane opportunity of the pre-war years (HILMERA, LAJCHA and ZACH 1983: 8).

The third time Vychodil designed for The Taming of the Shrew was 35 years later in Bulgaria. Unfortunately, there are no archive materials nor sketches or photographs known to document this production. Vychodil briefly mentioned it to Jarka M. Burian on one of the audio tapes archived at the Jerome Lawrence and Robert E. Lee Thea-

3 For example: W. Shakespeare: Julius Caesar, National Theatre in Prague, 1936 or J. Cocteau: The Knights of the Round Table, National Theatre in Prague, 1937. 
tre Research Institute. From what was audible on the tape, he mentioned bicycles in a relatively small theatre space. It would be audacious at the present state of knowledge to conclude more out of such scarce material, however further archive material has recently been made available by the family, and there might be more clues also to the scenographic designs of this production.

On the other hand, Vychodil created a more complex setting for As You Like It, and especially his treatment of the forest of Arden became a solution he liked further to reinvent. The production was directed by Jozef Budský (1946 Slovak National Theatre), and it was one of the most significant post-war theatre pieces. It called upon the imagination of the audience that was to be suppressed by the authorities in the following years. In the theatre programme editorial, Budsky wrote that the primary task of the theatre for the upcoming season was to bring such 'ideas and create images that would provide optimism and joy as well as captivate the audience longing for knowledge and happiness' (HILMERA, LAJCHA and ZACH 1983: 8). Budský interpreted the play as two opposing worlds. The palace - appearing as perfect at first sight was in many respects only 'a rotten prison full of deception and egoistic needs of some individuals' (BUDSKÝ 1946). The forest garden represented a dreamy Rousseau-like world, where people lived in harmony with nature. Both for the forest as well as for the palace the stage light was a vital mood setter. The enclosed, yet open, solid, yet see-through abstract structure created a contrast to the forest of Arden comprising specific objects and images resembling a forest. Thanks to the light, both spaces got a sensation of the opposite, the forest seemed unreal and fairy-tale like, whereas the palace looked more real. However, as Budský wrote in the programme, the comedy had no logic. Instead, it was a beautiful dream that Shakespeare dreamt, and according to Budský, it was worth having a chance to dream it along with him.

Vychodil managed to create a space meeting the needs of Budskýs interpretation. He was inspired by the stage setting František Tröster created for As You Like It in Prague in 1937. For this production, Tröster used two round raked stages as grasscovered islands. They overlapped each other and revolved clockwise and anticlockwise in opposite directions. Together with the projections of leaves, the atmosphere of the forest of Arden was to be playful and free, in contrast to the court, which was separated by three translucent curtains. The decking of Vychodil's stage was similarly uneven, and he also made use of the revolving stage to develop more mysterious arrivals and retreats to and from the scene. Like Tröster, Vychodil used a projection of trees and leaves on the backdrop to contrast with the real stage props. Some of the accessories were plastic, but he also used some live tree branches. Essential elements of the stage were the materials he used and the way they were lit. To create a magical atmosphere of the forest, Vychodil experimented with a projection through several layers of nets and metal grids. He used different thickness of the netting with various shapes of the central entering space which allowed the light to cast shadows on the stage floor and the layers of vertical fabric and materials comprising the set, with both specific and abstract patterns. The idea of restricting the stage from the frontal view and allowing only a relatively small peak behind the panels with nets or grids reappeared in Vychodil's work 


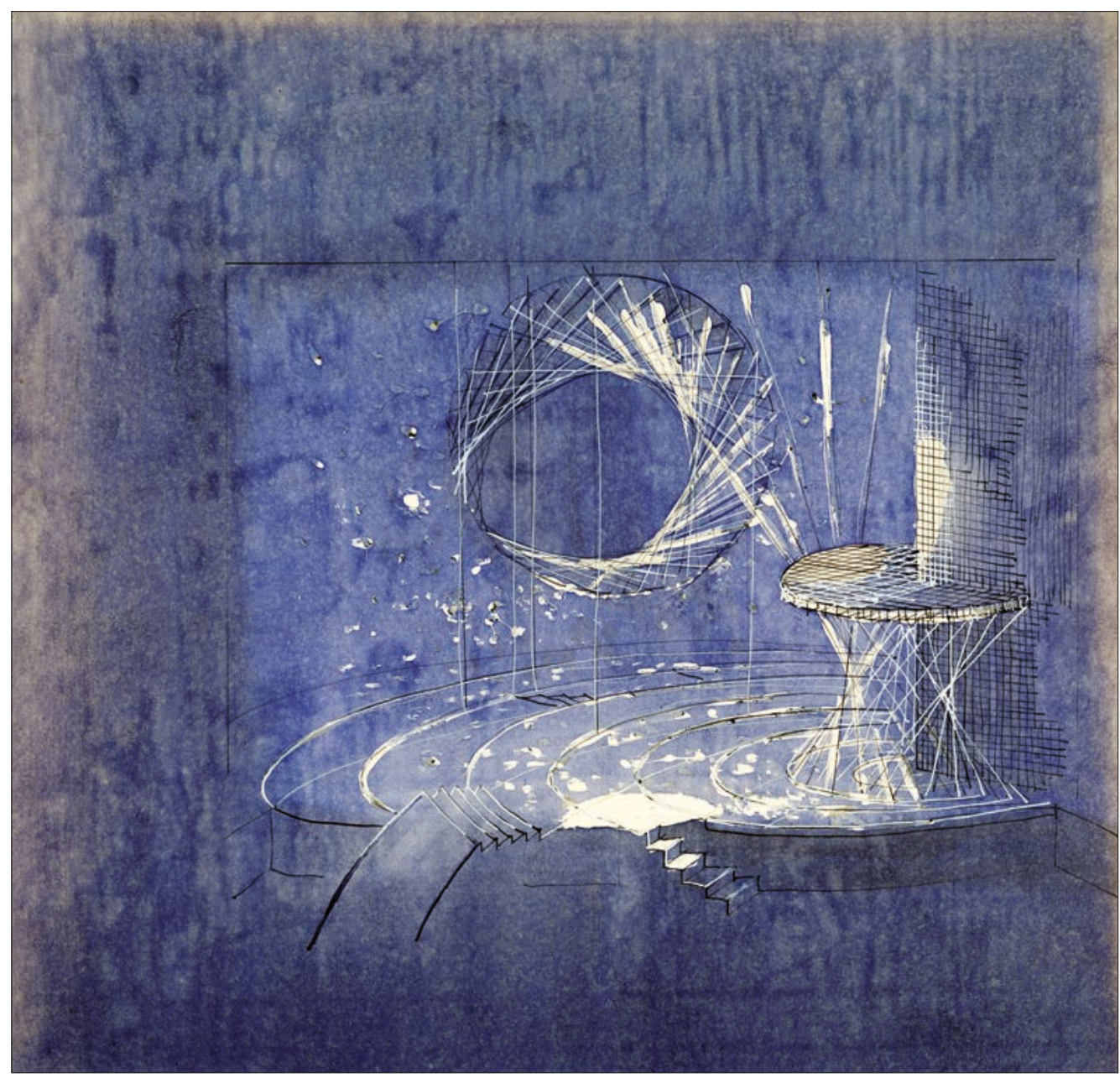

Fig. 1: Ladislav Vychodil: Comedy of Errors (direction: J. Cazalet) Concordia University, Montreal, 1984.

sometimes afterwards, especially for operas. He emphasised the idea of an escape to a magic land beyond the boundaries of the court even further than Tröster.

Budský intended to direct Richard III after the war but, according to his own words, 'the translation was rough and untheatrical, so we had to give up on it' (BUDSKÝ Unpublished). Bearing in mind the inclination of the political regime towards Socialist ideology, it is clear that the poor translation was not the only reason for the abandonment of a tragedy on crime, punishment and the rise and fall of the political power of a 'villain'4 until the 1969 production. ${ }^{5}$ The next Shakespeare allowed in the dramaturgi-

4 'And therefore, since I cannot prove a lover / to entertain these fair well-spoken days, / I am determined to prove a villain / and hate the idle pleasures of these days.' (Richard III 1.1.28-31).

5 King Richard III, 1969, Jonáš Záborský Theatre, direction: M. Bobula, stage and costume designs: J. Hanák. 
cal plan of the Slovak National Theatre was Hamlet in 1950. It was the most problematic period for Vychodil's scenography. Although he could develop and improve the theatre workshops, and also devote his time to teaching scenography at the newly established Academy of Performing Arts in Bratislava (1952), the time of Socialist Realism dictated not only what was to be produced but also what it should look like. The most critical notion was that the scenography should be understandable for everyone, historical accuracy and realism were highly encouraged. Vychodil used this period to develop his historical accuracy and monumental architectural structures. His account of the period and reasons why he turned towards this style was as follows:

We are in 1948. Remembering the period, I am trying to find out what was the most significant influence that changed our work. It was the realisation of the contradictions between our work and the surrounding life. But the most straightforward and the most significant drive was the conflict between the artwork and the actor [...] actors didn't fit in the stage, and they even impaired the visual impression of the stage by their sheer appearance on it. We dreamt about seizing the actor by the costume to make him an artistic visual part of the stage. (VYCHODIL 1953: 143)

On the other hand, 'a stage created according to some aesthetic speculations was an obstacle for actors' (VYCHODIL 1953).

There were only two productions of Shakespeare designed by Vychodil between 1948 and 1956 the so-called 'Sorela' the period of the strictest implementation of Socialist Realist ideas (KUSÁ 2017). The so-called Zhdanov's pan-realism, or the superior principle of realism, which in fact was not 'objective reality but the reality of its revolutionary development' (ZHDANOV 1934), was the only accepted method. Such reality was a utopian optimism that was forced upon people, and therefore it is not easy to unmask whose optimism was sincere and based on the belief in the ideology and whose optimism was just a survival mode.

The 1950 Hamlet was directed by three directors (J. Budský, T. Rakovský and I. Lichard) and was interpreted in a strictly historical manner, both regarding the loyalty to the text and the stage maintaining an illusion of a historically accurate part of a medieval castle. Vychodil even described his thought process developing from a symbolic, or at that time so called 'formalistic', stage into a more sensible and more understandable design:

The primary objective in the production of Hamlet was explicit: to create an environment that would be historically specified within a specific period, and the historical specificity would help to maintain the belief of the audience that the story took place at the end of the Gothic times. [First, he described a sketch with the pillared arcade. Such a set could have been used for any play of that specific period, so he dismissed it and stressed a new demand on the stage: the need for the right atmosphere.] Sketch number five has taught us that we can achieve the required atmosphere quite quickly by using an expressionistic stage. But such a solution would definitely be wrong. (VYCHODIL 1950) 
The scenographer and the directors decided not to rely on presumptions concerning an audience with art education, but instead tried to address an audience that does not know anything about the functions of art styles, deformations and 'isms', and considered the audience that comprehended things purely rationally. 'That is a door; you use it to enter a room, the room is small or huge and so on' (VYCHODIL 1950). That type of stage design could be called semantic scenography. The designer did not emphasise the visual effects; but instead, the function of mundane things [understood by each person in the same way] (VYCHODIL 1950).

The stage indeed appeared as if a proper reconstruction of a medieval castle. Vychodil paid attention to the finest details. Even the cemetery had real branches from trees representing bushes. In 1953, Vychodil wrote in an article for a Theatre Collective Volume that the goal of scenography was to emphasise the viewpoint of the audience and to maintain realistic work as that would keep them interested in theatre. 'Simple, transparent and comprehensible scenes with short changes. Those are new tasks for our scenography' (VYCHODIL 1953: 143). A widespread practice, among theatre researchers but also art historians, is to excuse seeming retardation of the style of many visual artists who tried to find their way of expressing the ideology proposed by the state. Whether Vychodil believed in the bright future of Socialist Czechoslovakia is hard to tell today, judging by the fact he did not suspend his practice, he persevered and taught new generations of students how to develop their talent beyond his shadow, he must have believed there was purpose in what he was doing. The archive material, as well as personal encounters with people who knew Vychodil, lead me to believe that, like many other artists, Vychodil also believed in the restoration of the system after the War. He came to Bratislava full of inspirations determined to continue the legacy of the pre-war Avant-Garde movements and the work of Tröster, Hofman, Muzika, Heythum, or E. F. Burian. Instead, he admitted in an interview with the historian Iva Mojžišová in 1980:

We have established that the previous development has amassed so many unique possibilities that we only need to sort the material and use it. How wrong we were! In the end, we simply began doing theatre that we thought the times we lived in required [...]. (MOJŽIŠOVÁ 2009: 259)

Another example from this period was the production of The Merry Wives of Windsor in 1954 directed by Karol L. Zachar. Here, he designed a relatively open stage with a painted backdrop and wooden parts that were criticised for squeaking and falling apart (SUCHÁNEK 2017). The stage, although conventional, worked well for the otherwise very successful production. Vyhodil used the period of Sorela to explore stagecraft from a different point of view; he wrote an academic article called 'On the Issues of the Socialist Realism in the Work of a Stage Designer" in which he also described the way space should be created. He explained the requirements of the proscribed Soviet example (Stanislavsky's method) as to how the space seen by the audience was only a section of a larger unit, whether that was a house or a flat or a forest (VYCHODIL 1953: 147). Vychodil sought philosophy beyond the mere description of reality and realised the 


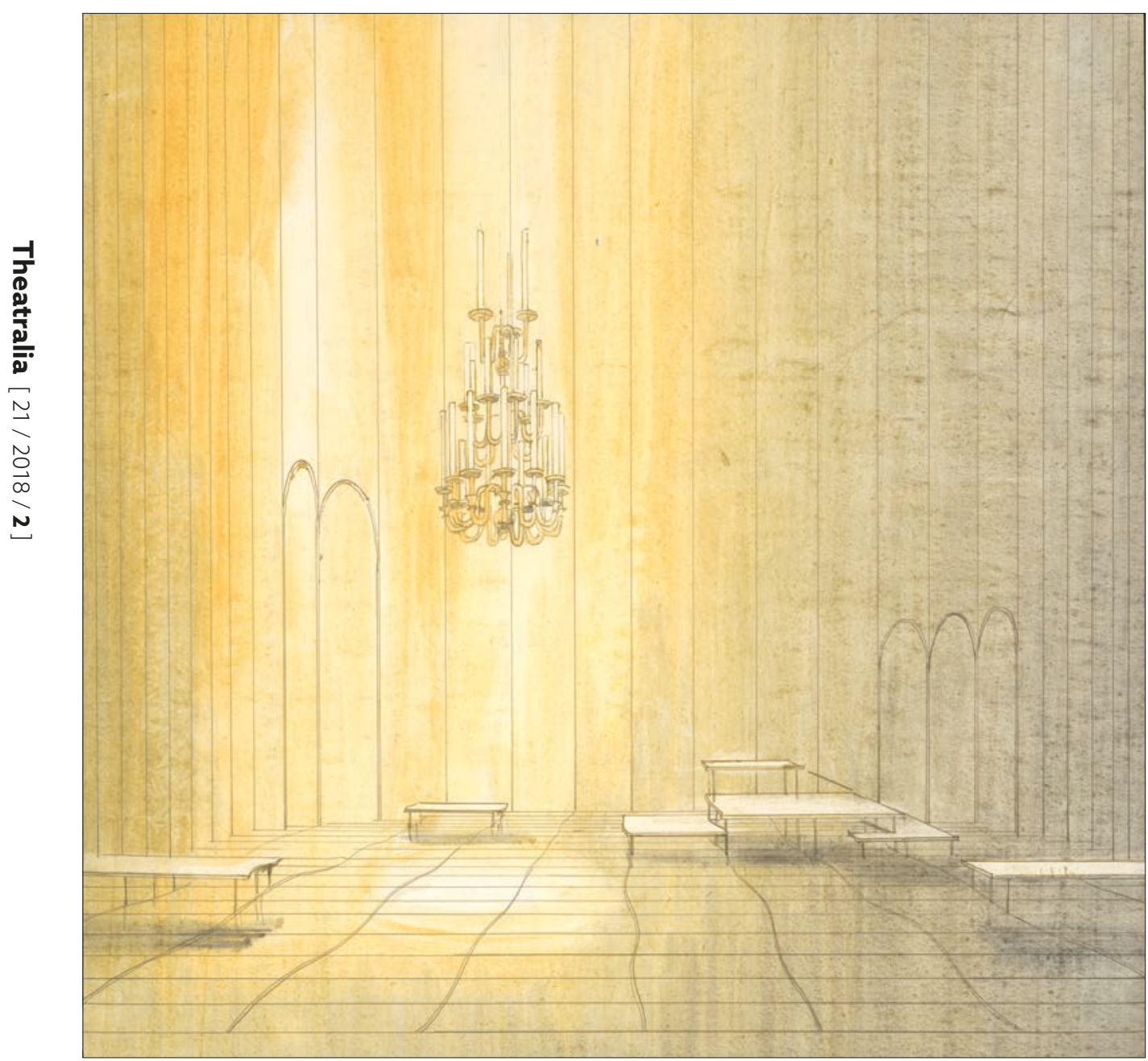

Fig. 2: Ladislav Vychodil: Twelfth Night or What You Will (direction: T. Rakovský) Slovak National Theatre, 1962.

limitations of such an approach very soon. His productions were becoming more functional and minimalist again. He also returned to his previous experiments with light and focused on shaping the space with light as one of the essential elements.

As I have already mentioned, Alfréd Radok is thought to have changed Vychodil's style when he began working with him. Radok was forced out of the National Theatre in Prague in 1959 and worked for Prague's Municipal Theatre. For Vychodil, it seemed that Radok changed his style entirely when he had to work in a small and poorly equipped theatre. However, Radok assured him there was no change in his style, and his aim remained 'to create theatre from theatre and its non-artistic means' (POLÁČKOVÁ 1990: 9). Indeed, it was partly because of lower budgets, smaller stages, poor technical equipment that Radok's productions were less technically sophisticated. 
On the other hand, Vychodil felt his adaptation to Radok's poetics was in a way a betrayal of his philosophy of simplicity. Vychodil developed a theory of the stage derived from the painting of Rembrandt. The neutral colours of the background could not work without the figures, and therefore he claimed, the stage should not be complete without the action of the actor (BURIAN and VYCHODIL 1975). Radok's approach of working with 'a collage of seemingly heterogeneous elements creating a layered feeling oscillating between completely different spheres' (POLÁČKOVÁ 1990: 8), shifted Vychodil's theory towards a more complicated reality of multiple layers and several depths of scenographic fields, inspired by Radok's previous work with the Laterna Magica. The way the film was adding another reality to the theatre production in which it was used, Vychodil added various layers of reality using combining stage props in surprising ways similarly to Surrealist paintings. More importantly, though, he was creating layers of space for the actors and chorus to create multiple realities at once even on a small stage. The production of Atlantis in $1961^{6}$ became the most emblematic creation and marked his step outside the boundaries of the inspiration coming from his teacher and initiated a new era in Vychodil's work. He developed his unique linear graphic style of relatively empty and straightforward stages, usually neutral in colour or see-through. The tone of the scene was then achieved using coloured lights. The different layers of reality were brought to the stage by various hanging linear objects and stage properties that carried multiple meanings depending on the way they were used by actors.

Returning to Shakespeare productions perhaps the best examples of such approaches are Twelfth Night in 1962, The Merry Wives of Windsor in 1972 and the Comedy of Errors in 1984. The stage decking of the Twelfth Night production was also slightly elevated and broken by a smaller cascade platform. The lines on the floor echoed the edges of the hanging objects as well as the backdrop of blinds consisting of vertical plastic seethrough stripes. The screens allowed differentiations in the mood; and setting lighting from behind strengthened the atmosphere of a fictional kingdom of Illyria. For example, warm yellow diffused light was used to illuminate a chandelier-like linear object which evoked interior spaces; whereas cold blue light was used for an area with a linear hanging object resembling a ship, which evoked the sea and travelling.

When Vychodil had a chance to design The Merry Wives of Windsor again in 1972 in Ostrava, he went back to the visual means he developed in the 1960s. Graphic semiotic objects could also be used as stage properties or could be only decorations. In the Ostrava production, there were three hanging objects: a house representing exterior spaces when it descended onto the stage; a bed representing interior locations, and a flower representing nature. Visual hanging objects and linear graphic patterns became Vychodil's signature style elements especially after meeting Radok.

In Hamlet of 1963, in Brno, Vychodil used a large net with holes as vault shaped windows and doors instead of simulating the walls of the Czech city's famous Kronborg castle. The net curtain or wall ran around the stage from three sides creating a constraint space of the 'rotten' castle, in the 'rotten' country. Space was both solid and see-

6 V. Nezval: Atlantída [Atlantis], Slovak National Theatre, 1961, direction: T. Rakovský. 
through similarly as in his As You Like It in 1946. The design also shows that Vychodil continued with developing the idea of linear objects that were not meant for practical use but carried a symbolic meaning. The hanging ship and the globe represented Hamlet's journey abroad and his arrival home. This production of Hamlet demonstrated a shift from descriptive Socialist Realism, although the structure of the castle is easily recognisable, at the same time, the principle of multiple reality and graphic linear objects were applied. Vychodil had shifted even further from the descriptiveness into complete structural linearity in the production of Hamlet in Zlín 1976 and even closer to Radok's principles in the production of Hamlet with the director Bedřich Jansa in 1988 in Ostrava. In fact, he had tried out all of his main scenography principles on the productions of Hamlet. I will devote more time and space to Vychodil's Hamlet productions in a different study.

A mature version of Vychodil's principles inspired by Radok came to fruition in the production of The Comedy of Errors in Montreal, Canada in 1984. The lighting was sophisticated and combined with projection effects that were both abstract and specific. Vychodil even incorporated a movie sequence in the action of the actors which was not so typical for his scenography, especially in Bratislava. The director's approach in Montreal was 'a space odyssey in the cosmos' as a search for loved ones and identity. Vychodil's favourite linear graphic objects were more than suitable for a semi-abstract representation of infinite space. The semi-circular stage with a high semi-circular platform on one side, supported by thin reclining crisscrossed poles, was echoed by the circular lines of force on the floor. Vychodil started experimenting with similar structures as early as 1947, in the production of Ave Eva in Bratislava. The idea though can be traced back to Tröster and his designs for exhibitions. ${ }^{7} \mathrm{~A}$ black and white photograph of a large-scale model box with a set of wires connecting in skewing lines two disks above each other is just a reminder of the roots of the linear objects and the use of this pattern. The curved cyclorama was used for projections of atmospheric images, which were hand painted on glass slides by Vychodil, and was decorated with a hanging circle with a linear filling, evoking the moon. He also used this moon object as a surface for the projection of other images, such as the faces of the characters. That time, Vychodil relied on visual projection much more than he usually did at home. In one of the interviews, he even admitted he didn't like to use technology too much, as opposed to his contemporary colleague Josef Svoboda for whom mechanical and technical invention was the soul of scenography.

After the success at the Sao Paolo Biennale in 1967 at which Vychodil received two gold medals for his exhibition, more and more theatres outside Czechoslovakia became interested in cooperating with him. In fact, Vychodil only designed three productions before 1967 outside Czechoslovakia. He received an invitation to teach a scenography course at the University of California, Santa Barbara in 1973, and in 1982 he participated at a conference in Canada at the Concordia University, Montreal. The conference

7 For more information see: http://www.troster.cz/akce/vystava-2007/vystava-2007-expozice/ [Retrieved 20. 11. 2017]. 


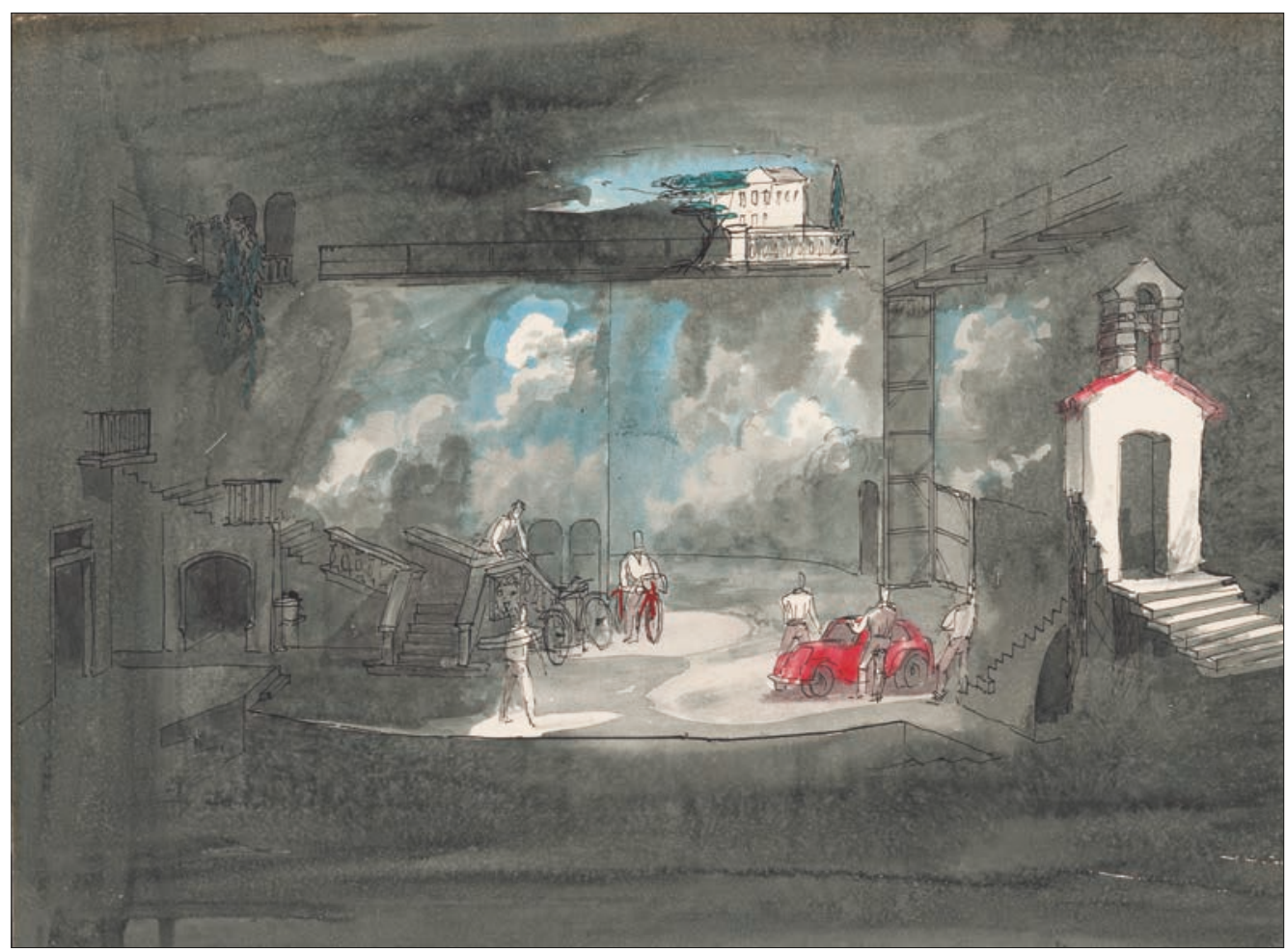

Fig. 3: Ladislav Vychodil: Romeo and Juliet (direction: P. Løkkeberg) Det Norske Teatret, Oslo, 1985.

was titled CONTACTS/82 (Conference to Advance Canadian Theatre Scenography). Vychodil had three lectures at the occasion, including the keynote talk on scenography. The University invited him respectively to create a stage design for Shakespeare's The Comedy of Errors in 1984. As far as scenography was concerned, the remaining renderings are very similar to those for Vychodil's acclaimed production of Atlantis at the Slovak National Theatre in 1961. The production renderings were among those awarded a prize in Sao Paolo, and it seems likely that Vychodil was either asked to create something of that kind or naturally thought himself that such a return to his work of more than twenty years ago was the best way to demonstrate his stage design principles in Canada.

Summarising all the approaches mentioned above, the best production appears to be Romeo and Juliet (direction: P. Løkkeberg) for Det Norske Teatret, Oslo, 1985. The renderings represent another aspect of Vychodil's work. His thought processes. A series of Vychodil's sketches show the way he developed the idea for the whole stage. Even more interesting than the designer's thought process, is the context of the production itself. On the day of the première of Romeo and Juliet the company of Det Norske Teatret, which represented the so-called 'New Norse' or rural dialects of the coastal regions of Norway within the premises of the Capital Oslo, finally got their building. It was inaugurated in 
the presence of King Olav and the leaders of the government. This was the beginning of a new era, as the building was at that time one of the largest theatres in Northern Europe. To present the stage in its whole greatness, they chose Romeo and Juliet and invited Vychodil to build a 'life-size Verona of the 1980s'. The stage was so enormous that Vychodil could use a real Fiat car and bicycles. One of the reviewers commented on the stage with a harsh critique:

\begin{abstract}
There was a lot of running to and fro and up and down stairs, and voices often had to compete with excessive distance [...] spectators seated in the front rows risked a crick in the neck from straining in awkward directions. The Czechoslovak stage director, Ladislav Vychodil, should have known better. His most effective scene, from proportions, was the one in the funeral vault, precisely because it was given in a confined space. The vault was elevated from below on the stage level both at the beginning and the close of the play and framed the play's largely comic central proportions with tragic emphasis. (SMIDT 1986: 111-114)
\end{abstract}

Despite the fact, the production did not get very positive reviews, the point I wanted to make is that Vychodil tried out almost all of his approaches within the stage designs for this production. There were realistic architectural structures such as staircases, vault gates and balconies. There were also various projections both on the backdrop as well as more intimate and mysterious video projections of faces within the frontal plans of the stage. Vychodil also used his favourite objects such as Baroque chandeliers, although the setting was the 1980s; and he also designed sophisticated lighting systems, for example, the study for the bed shows that it was lit from below. Along with the visual projection of Julia's face at the cemetery, there was also a linear structure projected on the side of the stage creating a geometrical contrast to the soft and magical face.

\title{
Conclusion
}

According to his philosophy, 'until the work had been proven abroad, you could do whatever you liked at home, and it would still mean nothing' (ČINČERA 1965). Vychodil used all of his previous approaches and put them together for the Oslo production of Romeo and Juliet. Although my present study does not tackle all of his Shakespeare productions, this overall summary of Vychodil's various creative solutions provides an overview of the main ideas he developed in his stagecraft throughout his whole career. Trying to concentrate on Vychodil's scenographic collaborations in foreign countries, one realises how little information has penetrated the borders of Czechoslovakia, and despite his successes overseas, the reports published by the national newspapers were so unfairly factual and nondescript. Vychodil admitted in an interview with Jarka Burian that he designed for productions of plays that were forbidden in Czechoslovakia such as Kafka and therefore could not 'brag about those back at home' (BURIAN and VYCHODIL 1975). There are in Czech and Slovak several catalogues, monographs, numerous studies and articles concerning various aspects of his work, but most of 
them talk about his domestic (Czech and Slovak) scenography in detail whereas about his work abroad the information is somewhat scarce. Thanks to Jarka Burian, a respected English language scholar on Czech theatre, the Jerome Lawrence and Robert E. Lee Theatre Research Institute in Columbus, Ohio possesses unique material on Ladislav Vychodil's scenography collected outside the Czech and the Slovak Republics. This under-researched material could provide a yet undiscovered perspective on $\mathrm{Vy}$ chodil's work allowing more comprehensive and sophisticated comparisons among his designs for domestic and foreign stages.

\section{List of Vychodil's scenography for Shakespeare:}

1. The Taming of the Shrew, Beskydy Theatre, Hranice na Moravě, 1944, director: J. Jahn.

2. The Taming of the Shrew, The New Stage of The Slovak National Theatre, Bratislava, 1946, director: D. Želenský.

3. As You Like It, The Slovak National Theatre, Bratislava, 1946, director: J. Budský.

4. Hamlet, The Slovak National Theatre, Bratislava, 1950, direction: I. Lichard, T. Rakovský, J. Budský.

5. The Merry Wives of Windsor, The Slovak National Theatre, Bratislava, 1954, direction: K. L. Zachar.

6. The Merry Wives of Windsor, The Slovak National Theatre, Bratislava, 1958, direction: K. L. Zachar (renewed).

7. Twelfth Night, The Slovak National Theatre, Bratislava, 1958, direction: T. Rakovský.

8. Hamlet, The State Theatre, Brno, 1963, direction: E. Sokolovský.

9. King Lear, The State Theatre, Brno, 1969, direction: A. Hajda.

10. The Merry Wives of Windsor, The State Theatre, Ostrava, 1972, direction: B. Jansa.

11. Much Ado About Nothing, The State Theatre, Brno, 1973, direction: R. Jurda.

12. Antonius and Cleopatra, The Workers Theatre, Zlin, 1974, direction: A. Hajda.

13. Twelfth Night, The Workers Theatre, Zlin, 1975, direction: A. Hajda.

14. Much Ado About Nothing, Tyl's Theatre, Prague, 1976, direction: G. P. Asimov.

15. Richard II, The Slovak National Theatre, Bratislava, 1980, direction: M. Pietor.

16. The Taming of the Shrew, Teatr Asparuch Paunov, Mikhaylovgrad, 1981, direction: E. Michajlova.

17. Othello, The State Theatre, Brno, 1982, direction: A. Hajda.

18. The Comedy of Errors, Concordia University, Montreal, direction: J. Cazalet.

19. Henry IV, The Slovak National Theatre, Bratislava, 1984, direction: M. Pietor.

20. Romeo and Juliet, Det Norske Teatret, Oslo, 1985, direction: P. Løkkeberg.

21. Richard III., The Slovak National Theatre, Bratislava, 1987, direction: M. Pietor.

22. Hamlet, The State Theatre, Ostrava, 1988, direction: B. Jansa.

23. Hamlet, The State Theatre, Brno, 1988, direction: A. Hajda.

24. Macbeth, The State Theatre, Ostrava, 1989, direction: K. Brynda.

25. The Winter's Tale, The Moravian Theatre, Olomouc, 1993, direction: B. Jansa. 


\section{Bibliography}

BUDSKÝ, Josef. Ak sa v krátkej retrospektíve obzrieme... [Pamäti]. [If We Look Back in a Short Retrospective [...] Memoirs]. Unpublished typewritten material from the Archive of the Theatre Institute in Bratislava.

BUDSKÝ, Josef. 1946. Do novej sezóny - so Shakespearom [New Season with Shakespeare]. As You Like It [Bulletin]. Bratislava: Slovenské národné divadlo, 1946, premiere 12. 10. 1946.

BURIAN, Jarka. M. 1981. Alfred Radok's Contribution to Post-War Czech Theatre. Theatre Survey 22: 2 (November 1981): 223. Downloaded from https://www.cambridge.org/core. The University of Hull, on 16 Nov 2017 at 22:48:00, subject to the Cambridge Core terms of use.

BURIAN, Jarka M. and Ladislav VYCHODIL. 22. 4. 1975. Personal Communication [JAB. CD. 1.1.] Archive of the Jerome Lawrence and Robert E. Lee Theatre Research Institute in Columbus, Ohio.

ČINČERA, Radúz. 1965. Rozhovory s Vychodilom [Interview with Vychodil]. Bratislava: Televízna filmová tvorba, 1965, 15:43-16:10. Archive of the Theatre Institute in Bratislava.

HILMERA, Jiří, LAJCHA, Ladislav and Aleš ZACH. 1983. František Tröster. Bratislava: Tatran, 1983.

KUSÁ, Alexandra. 2017. Prerušená pieseň [online] (24. 6. 2017) [accessed 25. 6. 2016]. Available from: https://www.webumenia.sk/kolekcia/116

MOJŽIŠOVÁ, Iva. 2009. Giacomettiho smiech? [Giacometti's Laughter?]. Bratislava: Academy of Fine Arts and Design, 2009.

POLÁČKOVÁ, Dagmar. 1990. Ladislav Vychodil. Bratislava: Slovenská národná galéria, 1990.

R. Za legendou nášho divadelníctva [Behind the Legend of our Theatre]. Ladislav Vychodil (1920-2005). Hudobný život [Music Life] 37: 9-10 (2005): 8.

SMIDT, Kristian. 1986. Romeo and Juliet at Det Norske Teatret. Shakespeare Quarterly [online] 37: 1 (Spring 1986): 111-114 [accessed 19. 11. 2015 23:16 UTC]. Stable URL: http://www.jstor. org/stable/2870200

SUCHÁNEK, V. 15. 11. 2017. Personal communication at Café Berlinka in Bratislava (11:0013:00).

VYCHODIL, Ladislav. 1950. Problémy výtvarníka pri inscenácii Hamleta [Problems of the visual artist producing Hamlet]. Hamlet [Bulletin]. Bratislava: Slovenské národné divadlo, 1950.

VYCHODIL, Ladislav. 1953. Z problematiky socialistického realizmu v práci javiskového výtvarníka [On the Issues of Socialist Realism in the Work of a Stage Designer] Divadelny zbornik (1953): 143.

ZHDANOV, Andrej A. 1934. Soviet Literature - The Richest in Ideas, the Most Advanced Literature. Soviet Writers Congress [online]. 1934 [accessed 15. 6. 2016]. Available from: https:// www.marxists.org/subject/art/lit_crit/sovietwritercongress/zdhanov.htm 


\section{Mgr. Zuzana Koblišková}

University of Hull, United Kingdom

z.kobliskova@gmail.com

Zuzana Koblišková was a Curator of the Scenography Collections at the Museum of the Theatre Institute in Bratislava (with a specialisation in online database development, maintenance and digitising of the museum collections) from 2011-2017. Her research at the Museum has resulted recently in co-authoring a publication on the collections: A Small Museum with a Large Collection (A Guide to the Museum of the Theatre Institute). She earned her Master's degree in Art History at Comenius University in Bratislava, and she is studying for her PhD at the University of Hull researching Slovak Scenography for Shakespeare from 1920-1989. She is currently working at the Slovak National Gallery as a Documenter of the Digital Archives. 